\title{
Francisco de Goya and the Seizing Impenitent
}

\author{
Enrique J. Carrazana \\ Hawaii Pacific Neuroscience, Department of Family Medicine \& Community Health, John A. Burns School of \\ Medicine, University of Hawaii, Honolulu, HI, USA
}

\section{Keywords}

Epilepsy · Seizure · Exorcism · Art · Borgia · Goya

\begin{abstract}
The painting, St. Francis and the Dying Impenitent (1788) by the Spanish Baroque painter, Francisco Goya, is discussed by the author within the context of epilepsy and biographical events in the lives of both the saint and the painter.
\end{abstract}

(c) 2020 S. Karger AG, Basel

\section{Introduction}

Unexpected and enthralling epileptic paroxysms often lend themselves to religious interpretations $[1,2]$. The biblical view of epileptic seizures as demonic possessions started to erode in the 19th century, as the concept of epilepsy as a brain disorder became more widely accepted. Within this religious framework, epilepsy has occasionally been a subject of the arts. Rafael's last painting, La Trasfigurazione [The Transfiguration] (1520), and Peter Paul Rubens depiction of St. Ignatius Loyola and the possessed (c. 1617) are among the best known and most accurate depictions of seizures during the Renaissance and Baroque periods, respectively [3].

karger@karger.com

(C) 2020 S. Karger AG, Basel

www.karger.com/ene

Karger!

\section{St. Francis Borgia and the Dying Impenitent}

San Francisco de Borja y el moribundo impenitente [St. Francis Borgia and the Dying Impenitent] (Fig. 1) was commissioned by Don Pedro de Alcántara Téllez-Girón, the 9th Duke of Osuna (1755-1807) for the chapel dedicated to St. Francis Borgia in the Cathedral of Valencia, painted in 1788 by Francisco Goya [4]. The saint was an ancestor of the Duke's wife, Doña María Josefa Alonso-Pimentel y TéllezGirón, Duchess of Osuna (1752-1834). The painting, located on the right wall of the chapel, presents a stunning mystical drama. The saint, dressed in simple robes, has his head encircled by a ring of divine light, which echoes the form of the window above him. Holding a crucifix in one hand and with the other hand raised in a gesture of consternation, he stares toward the impenitent. The torment is underscored by the dying man's heaving chest, sunken eyes, gasping mouth, rigid body, and the tousled bed sheets. Encroaching on the scene are 4 demonic creatures that hover in a cluster behind the impenitent sinner, their infernal origin indicated by the flames surrounding them. The symbolic gush of blood spurting from the healing crucifix alludes to a passage in the Book of Hebrews (9:14): “...the blood of Christ, who through the external Spirit offered himself without spot to God, shall purge your conscience from the dead works to serve the living God" [4].

Dr. Enrique J. Carrazan

Hawaii Pacific Neuroscience

St. Francis Sullivan Wing

2230 Liliha Street \#104, Honolulu, HI 96817 (USA)

ECarrazana@aol.com 


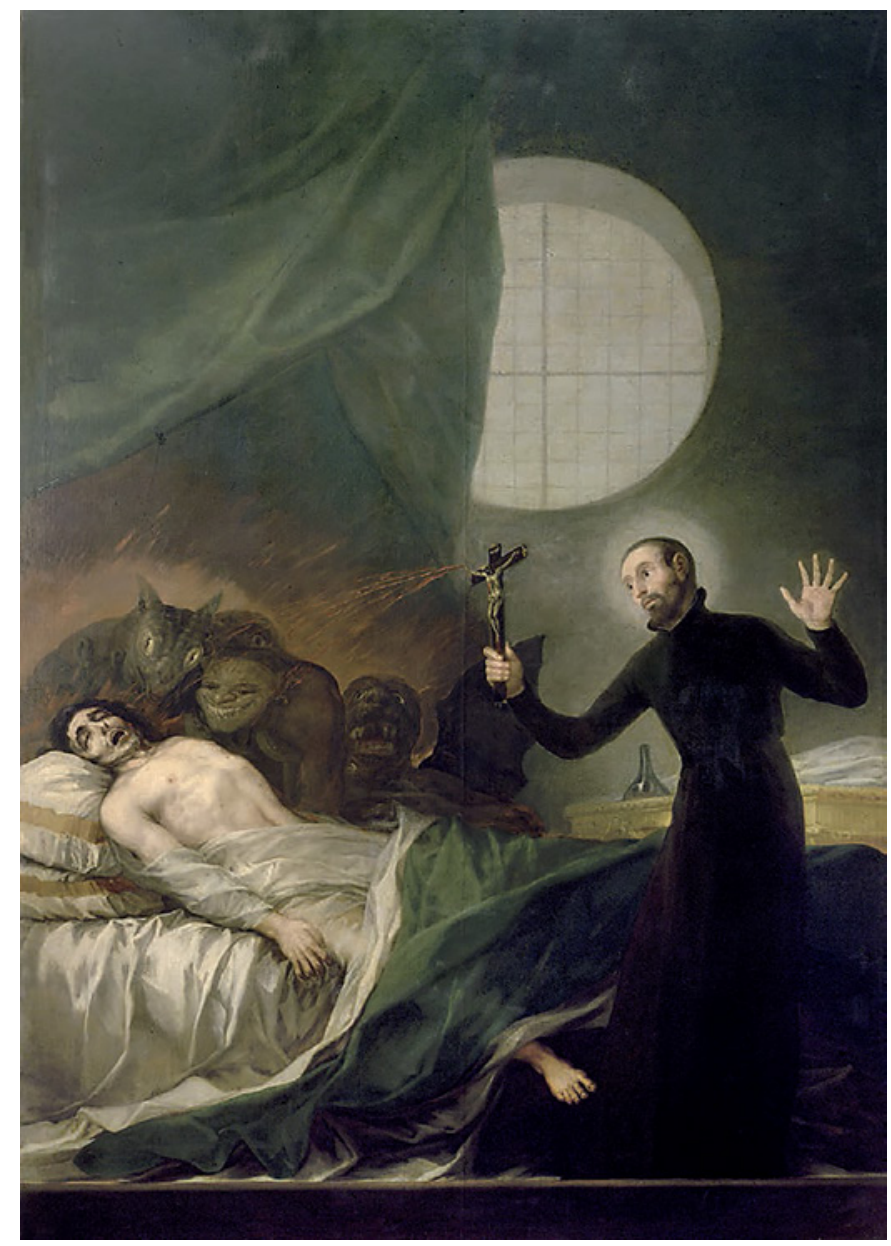

Fig. 1. San Francisco de Borja y el moribundo impenitente [St. Francis Borgia and the dying impenitent] by Francisco de Goya y Lucientes, 1788. Figure taken from Wikimedia Commons, the free media repository (Retrieved March 30, 2020).

While the scene depicted by Goya is often referred to as an exorcism, it is a representation of a man's death immediately following an epileptic generalized seizure. Goya based the scene on an account of the saint's life, which was written in an 18th-century biography by Cardinal Alvaro Cienfuego: La heroica vida, virtudes, y milagros del grande S. Francisco de Borja [The heroic life, virtues, and miracles of great St. Francis of Borgia] and is based partly on testimony given during the depositions for his canonization. The Cardinal described an indignant St. Francis hurling the bleeding crucifix and cursing the impenitent to eternal damnation, while the dying man gave an awful howl followed by convulsions $[5,6]$. Unlike other Renaissance and Baroque painters, Goya elected to depict the moment of death following the seizure. The impenitent man's closed eyes, gasping mouth, and decerebrate posture, contrast with the contrapposto pose of the seizing boy in Rafael's Transfiguration suggestive of a frontal lobe seizure (3). After St. Francis' death, his crucifix was carried to Peru by his grandson, Francisco de Borja y Aragón, Count of Rebolledo, Prince of Squillace (1581-1658), where it was tied to a miraculous cure of a person with epilepsy [7].

\section{St. Francis Borgia}

St. Francis Borgia (1510-1572) was born to the Duchess and Duke of Gandia in Valencia, Spain, on October 28,1510 . The great-grandson of both Pope Alexander VI (father of the notorious Lucrecia Borgia) and King Ferdinand V of Aragon, Saint Francis, was the Viceroy of Catalonia and part of Emperor Charles V's court. He was described as a pious man, who despite his wealth and political position, yearned for a life devoted entirely to Christ and the Catholic Church. After the death of his wife in 1546 , he joined the Society of Jesus and left his wealth and titles to his children. His devotion and political dexterity lead him to the position of Superior General of the Jesuits, 2nd only to St. Ignatius of Loyola. Despite the considerable power of his office, St. Francis led a humble life and was regarded in his own lifetime as a saint. He died on September 30, 1572, in Rome. He was beatified in Madrid on November 23, 1624, by Pope Gregory XV and canonized 36 years later on June 20,1670, by Pope Clement X $[5,7]$.

\section{Francisco de Goya y Lucientes}

Francisco de Goya y Lucientes (1746-1828) is considered the 18th century's foremost painter and etcher of the Spanish culture. A keen observer of human behavior, he was known for his realistic scenes of battles, bullfights, and depictions of human corruption. Goya was a royal court painter for Charles III and Charles IV, and later to Ferdinand VII. He lived during a time of upheaval in Spain that included the Inquisition, war with France, the rule of Napoleon, and finally the return of the Spanish Crown. Experts proclaim these events, and his later acquired deafness, as central to understanding his later work, which frequently depicts human misery in a satiric and nightmarish fashion. The St. Francis Commission was the 1st appearance for his supernatural monsters and demons, which later became an important and distinctive 
element of Goya's iconographic repertoire for his Pinturas Negras, Los Caprichos, and Disasters of Wars series, 30 years later [8].

\section{Discussion}

Seizures at end-of-life are a well-known occurrence. Little is known about the impenitent; other than that, he is described as a delinquente [criminal] [5]. The association of crime and alcoholism in 18th-century Spain is well established. A good proportion of felonies were alcohol related [9]. The link between alcohol abuse, traumatic brain injury, and seizures [10] could suggest an etiology for the impenitent man's seizure. In a large forensic series of seizure-related deaths, alcohol was linked to $34 \%$ of cases; significant brain pathology, which included contusions, subdural hematomas, subarachnoid hemorrhages, atrophy, tumors, and arteriovenous malformations, was described in about $47 \%$ of cases. Of relevance to the case at hand, the terminal seizure occurred at home in $70 \%$ of those cases [11]. The high incidence of subdural hematomas and contusions in alcoholics was noted in another forensic series of 195 cases, in which 22 patients suffered recurrent epileptic seizures [12].

St. Francis Borgia at the deathbed of an impenitent could be interpreted as abetting the demonic superstitions that were attributed to epilepsy during those times. The seizure heralds the eternal damnation awaiting the impenitent after a life of crime - the seizure as a punishment. However, Goya is known for his introverted, sarcastic, humanistic, biting satire of social attitudes, which hint at a double meaning in his painting $[6,8]$. The year that The Impenitent was painted, 1788 , is the year that the eldest son of Charles III, Don Felipe, was passed over for the throne of Spain in favor of his brother, Charles. Don Felipe had epilepsy and mild intellectual disability [13]; facts that Goya most certainly was aware of as a painter of the royal court. The comical depiction of the bedside demons transforms these symbols of darkness into those of folly and ignorance. Perhaps, Goya is telling us that the reason must prevail over the imagination and the mind must be ever vigilant against prejudice.

\section{Acknowledgements}

The author extends his gratitude to John Norwood, CMPP, and Kore K. Liow, MD for their manuscript's draft reviews.

\section{Statement of Ethics}

The author has no ethical conflicts to disclose.

\section{Disclosure Statement}

There are no financial disclosures.

\section{Funding Sources}

This work did not require funding.

\section{Author Contributions}

Dr. Enrique J. Carrazana satisfies all of ICMJE's authorship criteria.

\section{References}

1 Saver JL, Rabin J. The neural substrates of religious experience. J Neuropsychiatry Clin Neurosci. 1997;9(3):498-510.

2 Mann MW. The epileptic seizure and the mystery of death in Christian painting. Epilepsy Behav. 2010;17(2):139-46.

3 Janz D. Epilepsy, viewed metaphysically: an interpretation of the biblical story of the epileptic boy and of Raphael's transfiguration. Epilepsia. 1986;27(4):316-22.

4 Schulz A. The expressive body in Goya's saint Francis Borgia at the deathbed of an impenitent. Art Bull. 1998;80(4):666-86.

5 Cienfuego A. La Heroica Vida, Virtudes, y Milagros del grande S. Francisco de Borja. 4th ed. Barcelona: Sapera/Osset; 1754. Available from: https://archive.org/details/laheroycavidavir00cieguat/page/n265/mode/2up/ search/crucifijo.

6 Heckes F. Supernatural themes in the art of Francisco Goya. Ann Arbor, MI: University of Michigan; 1985.p. 15-6.

7 Clarke AM. The life of St Frances Borgia of the society of Jesus. London: Burns \& Oates, Ltd.; 1894. p. 104-8.

8 Smith PE, Chitty CN, Williams G, Stephens D. Goya's deafness. Pract Neurol. 2008;8(6):370-7.

9 Lopez-Lazaro F. Crime in early bourbon Madrid (1700-1808): an analysis of the royal judicial court's casebook, ch. VII-IX. New York/Ceredigion, UK: The Edwin Mellen Press; 2009.
10 Taylor LA, Kreutzer JS, Demm SR, Meade MA. Traumatic brain injury and substance abuse: a review and analysis of the literature. Neuropsychol Rehabil. 2003 Jan-Mar;13(12):165-88.

11 Copeland AR. Seizure disorders. The dade county experience from 1978 to 1982 . Am J Forensic Med Pathol. 1984;5(3):211-5.

12 Skullerud K, Andersen SN, Lundevall J. Cerebral lesions and causes of death in male alcoholics. A forensic autopsy study. Int J Leg Med. 1991;104(4):209-13.

13 Lopez-Cordon MV, Perez Samper MA, Martinez de Sas MT. La casa de Borbon. Madrid: Alianza Editorial; 2000. Vol. I, p. 1700-1808 